\title{
Culturable Fungi in Brown Bear Cave Dens
}

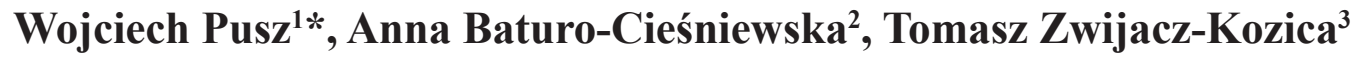 \\ ${ }^{1}$ Plant Pathology and Mycology Division, Department of Plant Protection, Faculty Of Life Sciences and Technology, \\ Wrocław University of Environmental and Life Sciences, Poland \\ ${ }^{2}$ Department of Molecular Phytopathology, University of Technology and Life Sciences, \\ Kordeckiego 20, 85-225 Bydgoszcz, Poland \\ ${ }^{3}$ Tatra National Park, Kuźnice 1, 34-500 Zakopane, Poland
}

Received: 4 May 2017

Accepted: 20 June 2017

\begin{abstract}
The analyses reported in the present paper aimed at determining the species composition and spore concentrations of airborne fungi in bear dens. Aeromycological analyses inside the dens were performed with the impact method using an Air Ideal 3P apparatus. Five bear dens were included in the survey - all located within Tatra National Park in southern Poland. Four dens had been used by females with one young or by solitary individuals, and another one had not been used for several years. The aeromycological analysis of the dens revealed the incidence of 13 species of fungi. Inside the dens in which the females with young had hibernated, the majority of spores represented the genus Penicillium. In the remaining dens the highest concentrations of spores were produced by the species P. glaucoalbidum. Furthermore, the airborne spores of Aspergillus niger, Botrytis cinerea, and Trichoderma spp. were found in the dens surveyed. In the dens used by females with young, the concentrations of CFU/m3 were lower, but the number of species of fungi was higher compared to the ones in which no young individuals hibernated. In the latter dens the values of $\mathrm{CFU} / \mathrm{m}^{3}$ reached levels potentially dangerous to human health.
\end{abstract}

Keywords: culturable fungi, airborne fungi, bear den, aeromycology

\section{Introduction}

Airborne fungal spores are so-called bioaerosols, which are dispersed in the air as droplets and as solid dust particles through skin and mucous membranes via respiratory routes, by piercing of blood-sucking arthropods, and - less often - through the alimentary route [1-2]. Bioaerosol-contaminated air may constitute an important source of infection, not only for humans but also for animals [3]. Most often, air inside such sealed spaces as caves, mineshafts, or tunnels are the fungi

*e-mail: wojciech.pusz@upwr.edu.pl of Cladosporium, Fusarium, and Penicillium genera. Penicillium spp. are capable of producing high numbers of spores that may affect the health both humans and animals. The spores may also contain mycotoxins and as such they are potentially the most sensitizing fungal organ known [4]. They may bring about severe disorders of the immune system as well as infections of internal and external organs of mammals. The taxa of Penicillium are mainly responsible for infections of skin, bone marrow, intestines, kidneys, and eye cornea. They may also cause pneumonia and endocarditis peritonitis, as well as urinary tract infections and allergies [5].

Until now, researchers' attention has focused on assessing the microbiological sanitary status of livestock 
buildings [3]. On the contrary, not many published articles deal with the problem of concentration and species composition of the fungal spores inside the objects that harbor large aggregation of wild animals, although the risk to their health may be similar. Recently, several series of aeromycological analyses were carried out in the underground fortifications of the World War II-era Międzyrzecz Fortified Region. There, the fungal spore concentrations were measured within the underground tunnels used as hibernation sites by bats. The concentration of the Aspergillus and Penicillium spores was high enough at some sampling sites to affect the health of the hibernating animals [6]. Other researchers had paid attention to mycocenoses of marmot burrows, where the incidence of dermatophytes was ascertained, and to the role of marmots as the source of infection for other mammals [7]. No such observations had been carried out hitherto in bear dens.

Hibernation is a physiological-behavioral adaptation that allows bears to survive through an inconvenient period of food deficiency. It may last even longer than seven months, although individuals from populations inhabiting warmer regions may stay active throughout the year [8]. The duration of the hibernation of bears varies across different populations. Generally, the higher the latitude, the longer the hibernation [8-9]. The pregnant females build their dens first and are the last to leave. The length of hibernation also depends on age; older females hibernate longer [10], whereas the opposite is true for males [11]. Adult males go into hibernation as the last individuals in a group, and they leave their dens first. It was found in 1975-99 in Yellowstone National Park in the United States that females start building their dens in the fourth week of September, but males do so in the second week of October, and in the fourth week of November (females) or in the first week of December (males), 90\% of the population is already hibernating. Leaving the dens begins in the second week of February (males), or in the third week of March (females), and, respectively, 90\% of the population has their dens left in the fourth week of April (males) or in the first week of May (females). Females with young stay relatively close to the den site $(<3 \mathrm{~km})$ until mid-May [9]. Bears usually show a high degree of affinity to the denning area. The exception is young males, who usually go into their first hibernation at the age of 2-3 in close proximity to their mother's denning area. Only in the next year do they set out on a long trek and build their next den at a considerable a distance from the previous one [11].

In different regions of the world the hibernating bears use various places to build their dens and elaborate upon them to different degrees, less or more labouriously [12]. Accordingly, a number of classifications and typologies exist for bear dens. An extensive review of denning conditions of bears worldwide has been compiled by Linnell et al. [8]. In brown bears, these authors distinguished dens that are:

- Dug in the ground or in an ant hill

- Situated in natural caves or in rock cavities
- Dug in snow cover.

- Hidden in a rotten tree trunk.

A more detailed Scandinavian classification [11] system denotes five classes of dens:

- Built inside an anthill.

- Excavated under an anthill.

- Dug into the ground.

- Dug under a rock.

- Open nests on the ground surface hidden by thick vegetation.

The latter type is mostly used by adult males [11]. Within Tatra National Park four den types have been described: in caves, under a windthrow, constructed next to a tree trunk, and built under dwarf mountain-pine shrubs [13].

Since the 1990s an intensive survey has been carried out within Tatra National Park, aimed at finding the hibernation dens of bears. The survey is mostly conducted in springtime and uses the backward bear tracing technique. A number of dens also have been found accidentally, between the late fall and springtime. These were considered hibernation sites based exclusively on their appearance, which, however, involves the risk of mistaking a briefly-exploited summer den for a true hibernation site of a bear [14]. In 1992-2011, 37 dens were found. Most often these were localized in natural caves $(46 \%)$, and less often next to a trunk of a densely branched spruce (35\%), where the bear typically had dug a shallow pit in the ground. The dens were localized at altitudes between 1,238 and 1,627 $\mathrm{m}$ a.s.1. (mean 1,461 m, $\mathrm{SD} \pm 108 \mathrm{~m}$ ), on slopes with inclination of $13-65^{\circ}$ (mean $41^{\circ}, \mathrm{SD} \pm 14^{\circ}$ ). Cold exposure involved the NE (nine dens) and $\mathrm{NW}, \mathrm{N}$ and $\mathrm{E}$ (eight dens in each) predominated. Four dens were found on the slopes of SE (2), S (1), and SW exposure (1).

\section{Materials and Methods}

\section{Study Area}

The study was carried out in Tatra National Park $(\mathrm{TPN})\left(19.95^{\circ} \mathrm{E}, 49.25^{\circ} \mathrm{N}\right)$ which covers completly the Polish portion of the Tatra Mountain range $\left(200 \mathrm{~km}^{2}\right)$ extending from their foot (800 $\mathrm{m}$ a.s.l.) to the highest peak of Rysy (2,499 m a.s.1.) (Fig. 1). The remaining portion of the Tatras, being the highest massif of the Carpathians, lies within Slovakian territory and is also protected by a national park. The Tatras are apparently alpine in their character. Their climatic and vegetation strata are clearly distinguishable and they include low mountain zone forests $(1,200-1,250 \mathrm{~m}$ a.s.1.), high mountain zone $\mathrm{f}$ orests (to 1,500 $\mathrm{m}$ a.s.1.), subalpine zone (to 1,800 $\mathrm{m}$ a.s.1.), alpine grasslands (to 2,300 $\mathrm{m}$ a.s.1.), and subnivean zone (from 2,300 $\mathrm{m}$ a.s.1. up). With increasing altitude the mean annual air temperature decreases from $5.4^{\circ} \mathrm{C}$ to $2.4^{\circ} \mathrm{C}$, and total precipitation increases from $1,100 \mathrm{~mm}$ to $1,700 \mathrm{~mm}$. The snow cover holds on average $110-250$ days in lower to peak zones, with its average thicknes 


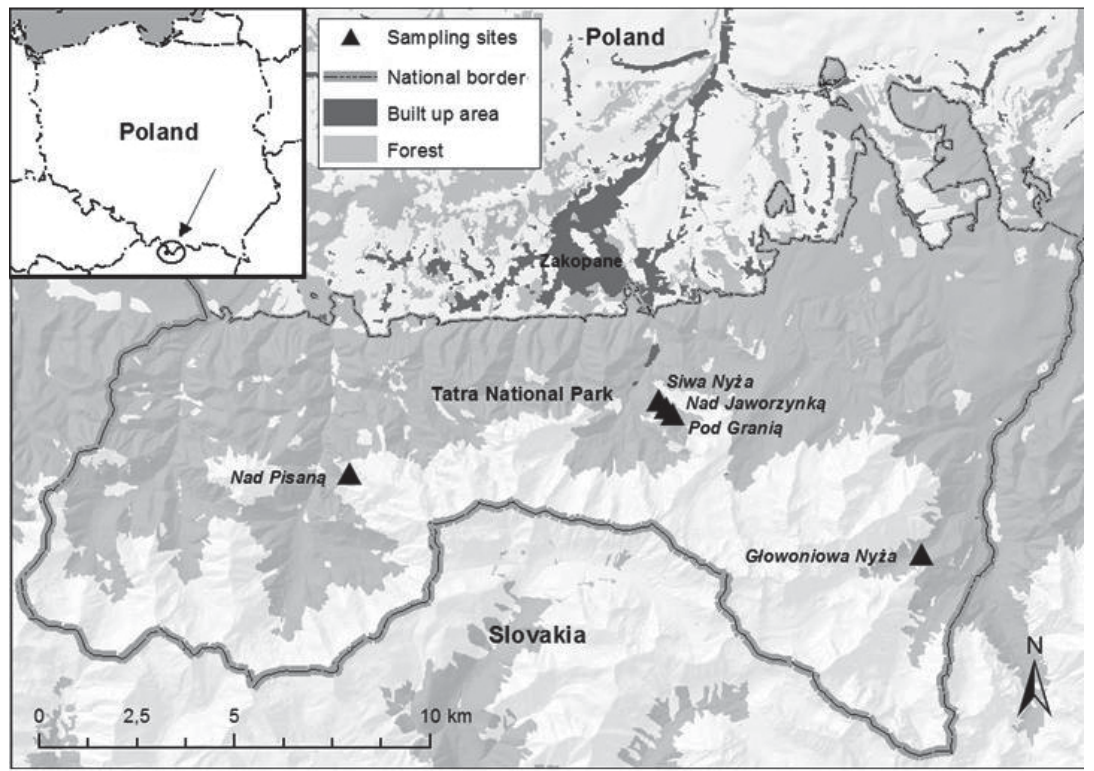

Fig. 1. Localizations of sampling points.

of 50-350 cm [15]. Predominant plant associations are spruce and beech forests, dwarf mountain pine shrubs, and alpine swards. The area has been under protection by the park since 1954. Since 2004 it has been also included in the Natura 2000 protection network. As the park is made available for visitors exclusively through the $270 \mathrm{~km}$-long network of tourist trails, stepping off the marked trails is strictly forbidden within the TPN area.

\section{Data Collection and Sampling Sites}

The analysis of the air inside the bear dens was performed using the impact method, using Air Ideal 3P apparatus and PDA (potato dextrose agar) growing medium by Biocorp. The air samples were taken in spring and summer 2015 in the following bear dens:

- Nad Jaworzynką: the first series of samplings was done in 2015; in winter 2014/15 a female without young hibernated here; during the next winter $(2015 / 16)$, a female with one young was found in the den.

- Nad Pisaną: an adult male hibernated here in winter 2015/16.

- Pod Granią: a female with one young overwintered in this den, probably in winter 2015/16.

- Głowoniowa Nyża: a female with one young overwintered in this den, probably in winter 2015/16.

- Siwa Nyża: this den has been uninhabited for at least five years.

In the course of the aeromycological analysis the air samples of $10 \mathrm{~L}$ and $50 \mathrm{~L}$ volume were taken. Within each den three measurements were taken constituting three replicates. Additionally, samples were taken in the surrounding of the dens. The material sampled onto the PDA medium was incubated at room temperature $\left(22^{\circ} \mathrm{C}\right)$ for seven days. After the incubation time elapsed, the colonies that appeared on the medium were counted and the fungi were identified taxonomically using their morphological traits (in 2015 samples), and based on genetic analysis (in 2016 samples). Subsequently, the number of colony forming units (CFU) had been calculated per $1,000 \mathrm{~L}\left(1 \mathrm{~m}^{3}\right)$ of the air in the dens. The calculation followed the formula:

$$
\mathrm{X}=(a \times 1000) / V
$$

...where $a$ is the total number of fungal colonies from the sampled air that had grown on a Petri dish, and $V$ stands for the air volume sampled (L).

The remnants of plants accumulated in the bear dens, such as branches, needles, hay and other material, were also subject to mycological analysis. Colony incubation and the identification of the fungal taxa was carried out according to the procedure identical to the one used for the material sampled from the air inside the dens. The next stage of the study was molecular analysis.

\section{DNA Isolation}

DNA was isolated from seven-day-old colonies cultured on the liquid glucose-potato medium (PDB, or potato dextrose broth, Difco). The obtained mycelium was rinsed with sterile water and drained using a flask, a Büchner Funnel, and a suction pump. Such prepared mycelium was lyophilized for $48 \mathrm{~h}$ in a CoolSafe lyophilizator (Scanvac), and subsequently homogenized with silica glass beads in a MagnaLyser (Roche) homogenizer. DNA was extracted of $30 \mathrm{mg}$ of the powdered mycelium using a Genomic Mini AX yeast kit (A\&A Biotech). The measurments of concentration of the DNA obtained were carried out using a Quantus fluorometer (Promega). DNA was diluted in deionized water to $20 \mathrm{ng} \cdot \mu^{-1}$ and stored at $-20^{\circ} \mathrm{C}$. 
PCR; Data Sequencing and Analysis

PCR was performed in $37.5 \mu$ volume that contained $2 \mathrm{mM} / \mu \mathrm{l} \mathrm{MgCl}_{2}, 0.25 \mathrm{mM} / \mu \mathrm{l} \mathrm{DTP}$, and $0.05 \mathrm{U} / \mu \mathrm{l}$ Taq DNA polymerase from 2xPCR MixPlus reagents (A\&A Biotech) and $0.6 \mathrm{pM} / \mu \mathrm{l}$ of each of the two following primers: ITS1: 5'-TCCGTAGGTGAACCTGCGG-3' and ITS4: 5'-TCCTCCGCTTATTGATATGC-3' [16], and $4 \mathrm{ng} / \mu \mathrm{l}$ DNA. Amplification was carried out in an Eppendorf Mastercycler according to the following reaction protocol: initial denaturation at $94^{\circ} \mathrm{C}$ for $5 \mathrm{~min}$., 35 cycles $\left(94^{\circ} \mathrm{C}\right.$ for $1 \mathrm{~min}$., $52^{\circ} \mathrm{C}$ for $1 \mathrm{~min}$., $72^{\circ} \mathrm{C}$ for $2 \mathrm{~min}$.) and final elongation at $72^{\circ} \mathrm{C}$ for $5 \mathrm{~min}$. The presence of the PCR products was verified by electrophoretic separation on the gel of $1.2 \%$ agarose concentration (Pronadisa). In order to visualize the reaction products in a transluminator, the SimplySafe fluorescent stain was added to the gel $\left(E_{\mathrm{X}}\right)$. The amplification products were purified and sequenced by Genomed (Poland). A BioEdit sequence alignment editor was used to analyze the obtained sequences (www.mbio.ncsu.edu/ bioedit/bioedit.html). ClustalW analysis was performed in a Mega6 Toolbar program. For taxonomical identification to the species level based on the sequence contigs, we used a basic local alignment search tool (BLAST) available from the National Center for
Biotechnology Information database (ncbi.nlm.nih.gov/ BLAST).

\section{Results and Discussion}

Fungi are an important part of underground ecosystems, playing diverse roles as decomposers, parasites, or food. They occur mainly on organic matter such as animal or human faeces, or on dead plant material. Inside the underground objects fungi are most often present as spores migrating with the air currents or with water, or are carried by the animals inhabiting such objects, i.e., by bats, rodents, or arthropods, but also by humans [17-18]. The fungal taxa most often found in the underground objects are those belonging to the genera of Aspergillus, Penicillium, Mucor, Fusarium, and Trichoderma, as well as Cladosporium and Alternaria [18-19].

Altogether, the incidence of 13 species of fungi were found in the aeromycological survey of the bear dens (Table 1) and in the neighborhood of dens (Table 2). Ten species were discovered at the springtime sampling of the air inside the Nad Jaworzynką den, several weeks after the female and her young had left the hibernation site. From each of the two other dens (Pod Granią and Głowoniowa

Table 1. Mycobiota of airborne fungi in cave dens $\left(\mathrm{CFU} / \mathrm{m}^{3}\right)$.

\begin{tabular}{|c|c|c|c|c|c|c|c|c|}
\hline \multirow{2}{*}{\multicolumn{2}{|c|}{$\begin{array}{c}\text { Name of cave den } \\
\text { Occurrence of brown bear }\end{array}$}} & \multicolumn{3}{|c|}{ Nad Jaworzynką } & \multirow{3}{*}{$\begin{array}{c}\text { Nad } \\
\text { Pisaną }\end{array}$} & \multirow{3}{*}{$\begin{array}{c}\text { Pod Granią } \\
\begin{array}{c}\text { Probably } \\
\text { female with } \\
\text { one young }\end{array} \\
\begin{array}{c}\text { Summer } \\
2016\end{array}\end{array}$} & \multirow{3}{*}{$\begin{array}{c}\text { Głowoniowa } \\
\text { Nyża } \\
\begin{array}{c}\text { Probably female } \\
\text { with one young }\end{array} \\
\text { Summer } \\
2016\end{array}$} & \multirow{3}{*}{$\begin{array}{c}\text { Siwa Nyża } \\
\begin{array}{c}\text { Uninhabited } \\
\text { for at least five } \\
\text { years }\end{array} \\
\text { Summer } \\
2016\end{array}$} \\
\hline & & \multirow{2}{*}{$\begin{array}{c}\begin{array}{c}\text { Female } \\
\text { without } \\
\text { young }\end{array} \\
\begin{array}{c}\text { Autumn } \\
2015\end{array}\end{array}$} & \multicolumn{2}{|c|}{$\begin{array}{l}\text { Female with one } \\
\text { young }\end{array}$} & & & & \\
\hline Fungal taxa & $\begin{array}{l}\text { Period of } \\
\text { sampling }\end{array}$ & & $\begin{array}{c}\text { Spring } \\
2016\end{array}$ & $\begin{array}{c}\text { Summer } \\
2016\end{array}$ & & & & \\
\hline $\begin{array}{r}\text { Allantopho } \\
\text { pseudo }\end{array}$ & $\begin{array}{l}\text { opsiella } \\
\text { igae }\end{array}$ & & & & & & & 20 \\
\hline Alternaria & Iternata & & 20 & & & & & \\
\hline Aspergill & niger & & & 60 & & 500 & 340 & \\
\hline Botrytis & nerea & & 45 & 60 & & 225 & 350 & 158 \\
\hline Mucor h & malis & & 134 & & & & & \\
\hline Penicillium $b$ & urgeianum & & & & & & 3,500 & 80 \\
\hline Penicillium & ommune & & 373 & 300 & & & 100 & \\
\hline $\begin{array}{l}\text { Penict } \\
\text { glaucoa }\end{array}$ & $\begin{array}{l}\text { ium } \\
\text { idum }\end{array}$ & 5,900 & 93 & & 6,500 & 3,500 & 650 & 340 \\
\hline Penicillium & inulosum & & 6 & & & & & \\
\hline Penicillium & wiecickii & 250 & 65 & & 234 & 200 & & \\
\hline Sydowia $p$ & yspora & & 26 & & & 100 & & \\
\hline Trichoderma & ningiopsis & & 10 & & & 100 & & \\
\hline Trichoder & a viride & & & & & & 256 & \\
\hline Yeast cc & nies & & 47 & & & & & \\
\hline TOT & & 6,150 & 819 & 420 & 6,734 & 4,625 & 5,196 & 598 \\
\hline
\end{tabular}


Table 2. Mycobiota of airborne fungi in the neighborhood of cave dens $\left(\mathrm{CFU} / \mathrm{m}^{3}\right)$.

\begin{tabular}{|c|c|c|c|c|}
\hline \multirow{2}{*}{ Fungal taxa } & \multicolumn{2}{|c|}{ Nad Pisana } & Głowoniowa Nyża & Siwa Nyża \\
\cline { 2 - 5 } & $\begin{array}{c}\text { Spring } \\
2016\end{array}$ & $\begin{array}{c}\text { Summer } \\
2016\end{array}$ & $\begin{array}{c}\text { Summer } \\
2016\end{array}$ & $\begin{array}{c}\text { Summer } \\
2016\end{array}$ \\
\hline Alternaria alternata & 20 & 125 & 75 & 340 \\
\hline Botrytis cinerea & 70 & 300 & 320 & 2 \\
\hline Epicoccum nigrum & 5 & 10 & 15 & 570 \\
\hline Penicillium commune & 20 & & 260 & 60 \\
\hline Penicillium glaucoalbidum & 20 & 240 & 80 & 5 \\
\hline Penicillium spinulosum & 25 & & & 16077 \\
\hline Penicillium swiecickii & 94 & & 920 & 5 \\
\hline Trichoderma viride & & 5 & & 5 \\
\hline TOTAL & 254 & 680 & & 5 \\
\hline
\end{tabular}

Nyża) that were most likely inhabited by females with their young, six species of fungi were recorded. The least species were found in the Nad Pisanq den, in which a male bear named Hugo had hibernated and, in 2015, in the Nad Jaworzynka den - the one occupied during the 2014/15 winter by a solitary female. In the last den, Siwa Nyża (the one uninhabited for less than five years), only four species of fungi were found.

Inside the dens in which the females with young had hibernated, the majority of spores collected represented the genus Penicillium. On the other hand, in the dens where no females with young overwintered, the highest spore concentrations were recorded for the species of P. glaucoalbidum - ca $6,000 \mathrm{CFU} / \mathrm{m}^{3}$ in the $\mathrm{Nad}$ Jaworzynką den in 2015 , and nearly $7,000 \mathrm{CFU} / \mathrm{m}^{3}$ in the Nad Pisaną den (the one occupied by Hugo, the male). $T$. penicillioides had been recorded in the Nad Jaworzynka den at the concentration level of $>90 \mathrm{CFU} / \mathrm{m}^{3}$ (when a female with her young hibernated there), at $650 \mathrm{CFU} / \mathrm{m}^{3}$ in the Głowoniowa Nyża den (most probably occupied by a female with young), and at $340 \mathrm{CFU} / \mathrm{m}^{3}$ in the unoccupied Siwa Nyża den. In the Pod Granią den (most likely female with young as well), the concentration of the spores of $T$. penicillioides reached a relatively high level, as it exceeded 3,000 $\mathrm{CFU} / \mathrm{m}^{3}$. The occurence of other fungi such as Aspergillus niger, Botrytis cinerea, or Trichoderma spp. was also recorded in the den air.

The highest concentrations of CFU per $1 \mathrm{~m}^{3}$ were found in two dens: Nad Pisana $\left(6,700 \mathrm{CFU} / \mathrm{m}^{3}\right)$ and, in 2015, Nad Jaworzynką $\left(6,100 \mathrm{CFU} / \mathrm{m}^{3}\right)$. These dens had been previously occupied by a solitary male and female, respectively. CFU concentrations at the level of 5,000 per $1 \mathrm{~m}^{3}$ were recorded in the dens in which most likely the females with young hibernated. These dens are: Pod Granią and Głowoniowa Nyża. Contrastingly, in the Nad Jaworzynką den, several weeks after the female with young had left, the CFU per $1 \mathrm{~m}^{3}$ reached merely the level of 800. The uninhabited den Siwa Nyża recorded a value of $600 \mathrm{CFU} / \mathrm{m}^{3}$.
The concentrations of the CFU inside the surveyed dens were many times higher compared to those found in the air samples taken outside in den surroundings (Table 2). The highest CFU concentrations were recorded in the close surroundings of the Siwa Nyża den $\left(>1000 \mathrm{CFU} / \mathrm{m}^{3}\right)$, whereas the lowest were found at the springtime sampling in the vicinity of the Nad Pisana den $\left(270 \mathrm{CFU} / \mathrm{m}^{3}\right)$. In the samples showing the highest total CFU concentrations, the species of $T$. penicillioides and $B$. cinerea, and the species of the genus Penicillium made up the highest proportion of the sampled material.

Out of the plant material collected in the bear dens, the greatest number of fungi (six species) was found in the Pod Granią den. The plant remnants from the Nad Pisaną den yielded three species, and two species were identified in each one of the two other dens: Nad Jaworzynką and Głowoniowa Nyża. The highest proportion of the fungi assemblage analyzed was shared by Mucor hiemalis (Nad Pisaną and Pod Granią dens). In the two other dens: Nad Jaworzynką and Głowoniowa Nyża, the colonies of Mortierella hyaline made the highest proportion of the assemblage (Table 3).

Of all the genera listed above, the highest proportion of the assemblages that were sampled from Tatra dens is shared by Penicillium spp.: P. biourgeianum, P. commune, P. swiecickii, and also P. glaucoalbidum. Penicillium spp. are well known as saprophytes and as secondary pathogens of plants. T. penicillioides is listed as one of the most important species responsible for the decomposition of spruce needles [20]; this may easily explain its relatively high proportion in the air samples both inside and outside the bear dens. Penicillium spp. taxa can also potentially negatively affect the health of humans and animals as they are the causal factor of severe infectious diseases [21] infections of internal and external organs such as skin, bone marrow, intestines, kidneys, and eye cornea. They may also cause pneumonia, endocarditis peritonitis, and urinary tract infections [22], as well as allergies in humans and in animals [23], and they are capable of producing 
Table 3. Fungi isolated from debris liter inside cave dens (number of colonies).

\begin{tabular}{|c|c|c|c|c|}
\hline \multirow{3}{*}{ Fungal taxa } & Nad Jaworzynką & Nad Pisaną & Pod Granią & Głowoniowa Nyża \\
\hline & $\begin{array}{c}\text { Female } \\
\text { with one young }\end{array}$ & Male & $\begin{array}{c}\text { Probably } \\
\text { female with one young }\end{array}$ & $\begin{array}{c}\text { Probably } \\
\text { female with one young }\end{array}$ \\
\hline & $\begin{array}{l}\text { Summer } \\
2016\end{array}$ & $\begin{array}{l}\text { Summer } \\
2016\end{array}$ & $\begin{array}{l}\text { Summer } \\
2016\end{array}$ & $\begin{array}{l}\text { Summer } \\
2016\end{array}$ \\
\hline Alternaria alternata & & 10 & 5 & \\
\hline Entomocorticium sp. & & & 10 & \\
\hline Mortierella hyalina & 21 & & & 24 \\
\hline Mucor hiemalis & & 45 & 55 & \\
\hline Penicillium commune & 7 & & 2 & 17 \\
\hline Sordaria fimicola & & 34 & 30 & \\
\hline TOTAL & 28 & 89 & 102 & 41 \\
\hline
\end{tabular}

high numbers of spores [18]. Penicillium taxa are also characterized by their ability to synthesize mycotoxins, which can consequently be found in underground objects $[4,24]$. As they intoxicate animal organisms via their alimentary and respiratory systems or by dermal contact, mycotoxins have an adverse effect on the health of exposed humans and animals [25]. In the Nad Pisana den, the observed concentration of spores was at the level of $6,500 \mathrm{CFU} / \mathrm{m}^{3}$, and in the one Nad Jaworzynką (when the female and her young were absent from the den), the
$\mathrm{CFU} / \mathrm{m}^{3}$ value reached nearly 6,000 . According to Polska Norma (the respective standard is No. PN-89 Z-04111/03), the air in the objects mentioned should be considered as contaminated and, as such, capable of adversely affecting human health (Table 5) [26]. Since 2015 there have been no microbiological air quality standards in Poland, so a description of good air quality is problematic.

Such a state of affairs indicates that a prolonged stay in bear dens, which may be the case when conducting scientific research, e.g., sampling, may be a potential

Table 4. BLAST analysis of fungi isolated from cave dens on IT parts (https://blast.ncbi.nlm.nih.gov/Blast.cgi?PROGRAM=blastn\&PAGE_ TYPE=BlastSearch\&LINK_LOC=blasthome).

\begin{tabular}{|c|c|c|}
\hline Fungal taxa & Identities $(\%)$ & Identity with sequence from NCBI \\
\hline Allantophomopsiella pseudotsugae & 100 & JN033384.1 \\
\hline Alternaria alternata & 100 & KX904867.1,KT895943.1 \\
\hline Aspergillus niger & 100 & KU847851.1, KU847850.1 \\
\hline Botrytis cinerea & 100 & KX721051.1, KT921335.1 KT898761.1,KT692578.1 \\
\hline Entomocorticium sp. & 100 & FR837930.1 \\
\hline Epicoccum nigrum & 100 & KU935700.1, KX664321.1 \\
\hline Mortierella hyalina & 100 & KC008878.1, JX975992.1 \\
\hline Mucor hiemalis & 99 & KM668138.1,KJ589587.1 \\
\hline Penicillium biourgeianum & 100 & KU561931.1, KT323160.1 \\
\hline Penicillium commune & 100 & KM519651.1, DQ132843.1 KF706682.1,KP670439.1 \\
\hline Penicillium glaucoalbidum & 99 & KU516608.1, AY618252.1 \\
\hline Penicillium spinulosum & 100 & KU319067.1, KM396383.1 \\
\hline Penicillium swiecickii & 100 & DQ267904.1 \\
\hline Sordaria fimicola & 100 & KU375685.1, KT323211.1 \\
\hline Sydowia polyspora & 99 & KU516594.1, KT693747.1 \\
\hline Trichoderma koningiopsis & 100 & KU645324.1 \\
\hline Trichoderma viride & 100 & KU516606.1, NR_138441.1 \\
\hline
\end{tabular}


Table 5. Description of scale air pollution and actinobacteria, bacteria, and fungi as recommended by standards of Polish Norm (PN-89 Z-04111/03).

\begin{tabular}{|c|c|c|}
\hline \multirow{2}{*}{ Air pollution } & \multicolumn{2}{|c|}{$\mathrm{CFU} / \mathrm{m}^{3}$} \\
\cline { 2 - 3 } & Bacteria & Actinobacteria \\
\hline Heavily contaminated & $>3 \times 10^{3}$ & $>1 \times 10^{2}$ \\
\hline Average contaminated & $1 \times 10^{3}-3 \times 10^{3}$ & $1 \times 10-1 \times 10^{2}$ \\
\hline Non-contaminated & $<1 \times 10^{3}$ & $<1 \times 10^{1}$ \\
\hline \multicolumn{2}{|c|}{\begin{tabular}{c} 
Fungi \\
\hline $\begin{array}{c}\text { The polluted air could be dangerous for } \\
\text { humans }\end{array}$
\end{tabular}} & $>1 \times 10^{4}$ \\
\hline $\begin{array}{c}\text { Air pollution could have a potentially } \\
\text { negative effect on humans }\end{array}$ & $5 \times 10^{3}-1 \times 10^{4}$ \\
\hline \multicolumn{2}{c}{ Clean atmospheric air } & $3 \times 10^{3}-5 \times 10^{3}$ \\
\hline
\end{tabular}

source of health risk, particularly in persons showing allergies to fungi [18-19]. It has been unknown so far whether or not the high concentrations of fungal spores do negatively affect the health status of animals inhabiting the dens. There is scant communication about the issue in scientific literature. Some authors firmly state that the incidence of some fungi species in the atmosphere of underground objects may negatively affect the health of the animal species living there, with bats making one example and the foremost reason being the ability of fungi to produce mycotoxins, or to infect the animal respiratory system, resulting in mycoses or other disorders [25, 27]. Investigations carried out in the hibernation sites of bats have demonstrated that - apart from a number of Penicillium species capable of producing mycotoxins - the spores of Aspergillus spp. were also present in the air of such objects, and that they were also a potential hazard to these animals. The highest concentrations of the spores of Aspergillus were recorded in January, similarly to those of Penicillium spp. It is possible that the spores of the two fungi species have been transported into the underground shafts with air currents or brought in by humans and animals, and they were subsequently developing on dead or live organic matter, e.g., on faeces [6] or on hay that is collected by bears before hibernation [3]. The greatest amount of hay collected by bears was found in the Nad Pisana den, in which only two species of fungi were found but in which, at the same time, the concentrations of the spores were the highest. In contrast, in the Nad Jaworzynka den, at the time when a female with young occupied it, the den's bottom was lined only with fresh branches of mountain pine and spruce, and it was in this den where the fungi species were found in the highest number, but the CFU values per $1 \mathrm{~m}^{3}$ were at their lowest. Most likely, the volatile compounds excreted from the stems of the coniferous plants had disinfected the air inside that den.

Among the other fungi species that were isolated from the dead plant remnants lining the dens' bottom, Mortierella hyaline deserves mention. This species had also been isolated by other authors from the soil in caves, and some researchers claim it is a component of underground objest mycocenoses [28]. In turn, Sordaria fimicola, being frequently isolated from the faeces of animals (including those spending some time in caves) [29] was isolated in the present study from the dens Nad Pisaną and Pod Granią. Interestingly, a fungus representing the genus of Entomocorticium was isolated from the bottom substrate of the Pod Grania den. Entomocorticium spp. are being described as components of the mycocenoses of corridors that are bored into spruce by many species of bark beetles. The species of the genus had been also isolated from bark beetles themselves. The role of these fungi in these insect developments or in the process of wood decomposition is not entirely known [30]. Other fungi in the present study were detected in den bottom substrates and are recognized as typical saprotrophs, e.g., Mucor hiemalis, P. commune, and Alternaria alternata. Some authors report that bears can possibly constitute reservoirs of fungi that are pathogenic to humans, including dermatophytes [31]. In the presented survey no such species were found.

An aeromycological study of brown bear dens in Tatra Mountains reported in the present paper was, to our knowledge, the first of its type worldwide. Communications published so far point to the hypothetical role of fungi in the process of den formation in trees [32], whereas no dens located in small caves or in rock crevices, as is the case in the Tatras, were investigated. Moreover, no interactions were analyzed in detail between the animal (bears), fungi, and the environment, although some fairly complex systems of interactions had been put forward. Rizzo [33] demonstrates that massive outbreaks of rust on Pinus albicaulis, resulting in the plants dying off, may affect grizzly bear populations, which, at higher altitudes, feed on the seeds of this plant. It therefore seems that research of this type should be extended not only to the mycological, but also the microbiological aspects. More attention should be paid also to chemical analyses of the den inside, with air analyses being as important as those of the chemical composition of the organic material lining the den bottom, for it may be reasonably presumed that the lining of the fresh conifer branches creates a disinfective barrier for the developing fungi, which might otherwise constitute a hazard for the young bears.

\section{Conclusions}

In the dens used for hibernation by females with young bears, low values of $\mathrm{CFU} / \mathrm{m}^{3}$ were recorded and, at the same time, more species of fungi were found compared to the dens in which solitary adult animals hibernated. In the dens used by a male, or by a female without young, considerably higher values of $\mathrm{CFU} / \mathrm{m}^{3}$ were recorded and, simultaneously, the number of fungal taxa isolated from these dens was lower. In the air inside the dens used by the 
solitary adult individuals the values of $\mathrm{CFU} / \mathrm{m}^{3}$ reached levels potentially dangerous to human health. Two fungi species were isolated out of the plant material lining the bottom of the dens. One of the species was Mortierella hyalina, and it was found in the den where a female with young hibernated. The other species, Mucor hiemalis, was isolated in the dens used by solitary adult individuals.

\section{Acknowledgements}

The authors gratefully acknowledge funding by the PGL Forest Fund "Lasy Państwowe (National Forests)."

\section{References}

1. MENTESE S., ARISOY M., RAD A.Y., GÜLLÜ G. Bacteria and fungi levels in various indoor and outdoor environments in Ankara, Turkey. Clean-Soil, Air, Water 37, 487, 2009

2. GÓRNY R.L., CYPROWSKI M., ŁAWNICZEKWAŁCZYK A., GOŁOFIT-SZYMCZAK M., ZAPÓR L. Biohazards in the indoor environment - a role for threshold limit values in exposure assessment. Management of indoor air quality. London: Taylor and Francis Group, 1, 2011.

3. PUSZ W., PLĄSKOWSKA E., WEBER R., KITA W. Assessment of the abundance of airborne fungi in cattle barn of dairy farm. Polish Journal of Environmental Studies 24, 241, 2015.

4. BRYDEN W.L. Mycotoxin contamination of the feed supply chain: Implications for animal productivity and feed security. Animal Feed Science and Technology, 173, 134, 2012.

5. PUSZ W., OGÓREK R. The potential harmful effect of fungi associated with tobacco material during storage on warehouse workers. Mikologia Lekarska, 19, 37, 2012.

6. KOKUREWICZ T., OGÓREK R., PUSZ W., MATKOWSKI $\mathrm{K}$. Bats Increase the Number of Cultivable Airborne Fungi in the "Nietoperek" Bat Reserve in Western Poland. Microbial Ecology 72, 36, 2016.

7. GALLO M., LANFRANCHI P. POGLAYEN S. Seasonal 4-year investigation into the role of the alpine marmot (Marmota marmota) as a carrier of zoophilic dermatophytes. Medical Mycology 43, 373, 2005.

8. LINNELL J.D., SWENSON J.E., ANDERSEN R., BARNES B. How vulnerable are denning bears to disturbance? Wildlife Society Bulletin 28, 400, 2000.

9. HAROLDSON M.A., TERNENT M.A., GUNTHER K.A., SCHWARTZ C.C. Grizzly bear denning chronology and movements in the Greater Yellowstone Ecosystem. Ursus 13, 29, 2002.

10. FRIEBE A., SWENSON J.E., SANDEGREN F. Denning chronology of female brown bears in central Sweden. Ursus 12, 37, 2001

11. ELFSTRÖM, M., SWENSON J. E. Effects of sex and age on den site use by Scandinavian brown bears. Ursus 20, 85, 2009.

12. NIELSEN S.E., MCDERMID G., STENHOUSE G.B., BOYCE M. S. Dynamic wildlife habitat models: seasonal foods and mortality risk predict occupancy-abundance and habitat selection in grizzly bears. Biological Conservation 143, 1623, 2010.
13. ZIĘBA F., ZWIJACZ-KOZICA T. On, czyli prawie wszystko o tatrzańskim niedźwiedziu. Tatrzański Park Narodowy, Zakopane, Polska. 2010 [In Polish].

14. MYSTERUD I. Characteristics of summer beds of European brown bears in Norway. International Conference on Bear Research and Management 5, 208, 1983.

15. FALARZ M. Seasonal stability of snow cover in Poland in relation to the atmospheric circulation. Theoretical and Applied Climatology 111, 21, 2013.

16. INNIS M.A., GELFAN D.H., SNINSKY J.J., WHITE T.J. PCR protocols: a guide to methods and applications. Academic press. 2012.

17. VANDERWOLF K.J., MALLOCH D., MCALPINE D.F., FORBES G.J. A world review of fungi, yeasts, and slime molds in caves. International Journal of Speleology 42, 77, 2013.

18. PUSZ W., OGÓREK R., UKLAŃSKA-PUSZ C., ZAGOŻDŻON P. Speleomycological research in underground Osówka complex in Sowie Mountains (Lower Silesia, Poland). International Journal of Speleology 43, 27, 2014.

19. PUSZ W., KITA W., WEBER R. Microhabitat influences the occurrence of airborne fungi in a copper mine in Poland. Journal of Cave and Karst Studies 76, 14, 2014.

20. KOUKOL O., BEŇOVÁ B., VOSMANSKÁ M., FRANTÍK T., VOSÁTKA M. KOVÁŘOVÁ M. 2008. Decomposition of spruce litter needles of different quality by Setulipes androsaceus and Thysanophora penicillioides. Plant and Soil 311, 151, 2008.

21. KUTTIN E.S., MÜLLER J. The fungal flora of zoo animals' ears. Mycoses 37, 59, 1994.

22. NIELSEN K.F., JENS C.F. Mycotoxins on building materials. Fundamentals of mold growth in indoor environments and strategies for healthy living. Wageningen Academic Publishers, 245, 2011.

23. CABRAL J.P. Can we use indoor fungi as bioindicators of indoor air quality? Historical perspectives and open questions. Sci of Total Environ 408, 4285, 2012.

24. PŁAWIŃSKA-CZARNAK J., ZARZYŃSKA J. Mycotoxins in food products of animal origin. Mikologia Lekarska, 17, 128, 2010.

25. SUANTHIE Y., COUSIN M.A., WOLOSHUK C.P. Multiplex real-time PCR for detection and quantification of mycotoxigenic Aspergillus, Penicillium and Fusarium. Journal of Stored Products Research, 45, 139, 2009.

26. POLISH NORM PN-89/Z-04111/03. Air purity protection. Microbiological analyses. Assessment of the concentration of microscopic fungi in the atmospheric air (ambient concentration) using aspiration and sedimentation method. Warszawa, Polish Committee for Standarization of Units and Quality 1989.

27. JURADO V., LAIZ L., RODRIGUEZ-NAVA V., BOIRON P., HERMOSIN B., SANCHEZ-MORAL S., SAIZ-JIMENEZ C. Pathogenic and opportunistic microorganisms in caves. International Journal of Speleology 39, 15, 2010.

28. OUT B., BOYLE S., CHEEPTHAM N. Identification of fungi from soil in the Nakimu caves of Glacier National Park. Microbiology \& Immunology 2, 26, 2016.

29. SALEEM M., LAMB B.C., NEVO E. Inherited differences in crossing over and gene conversion frequencies between wild strains of Sordaria fimicola from "Evolution Canyon". Genetics 159, 1573, 2001. 
30. KHADEMPOUR L., LEMAY V., JACK D., BOHLMANN J., BREUIL C. 2012. The relative abundance of mountain pine beetle fungal associates through the beetle life cycle in pine trees. Microbial Ecology 64, 909, 2012.

31. HUBÁLEK Z., RUDOLF I. Vertebrates as Hosts and Reservoirs of Zoonotic Microbial Agents. In: Microbial Zoonoses and Sapronoses. Springer Netherlands, 83, 2010.
32. BULL E.J., AKENSON J.J., HENJUM M.G. Characteristics of Black Bear Dens in Trees and Logs in Northeastern Oregon. Northwestern Naturalist 81, 148, 2000.

33. RIZZO D.M. Exotic Species and Fungi: Interactions with Fungal, Plant, and Animal Communities. Mycology Series 23, 857, 2005. 